\title{
Histopathology from the dissecting room: Are cadavers a suitable source of educationally useful histopathology specimens?
}

\author{
Andrew Wood ${ }^{1}$, Susan Whiten ${ }^{1}$, Jill McVee ${ }^{2}$, Jon Issberner ${ }^{1}$, David Jackson ${ }^{1}$, C. Simon Herrington ${ }^{3}$ \\ ${ }^{1}$ The School of Medicine, University of St Andrews, St Andrews, Fife, Scotland, United Kingdom \\ ${ }^{2}$ Biomedical Sciences Building, University of St Andrews, St Andrews, Fife, Scotland, United Kingdom \\ ${ }^{3}$ Division of Pathology, Edinburgh Cancer Research Centre, Institute of Genetics and Molecular Medicine, Western General Hospital, \\ University of Edinburgh, Edinburgh, United Kingdom
}

\begin{abstract}
Objectives: The requirement of the General Medical Council to 'reduce factual overload' has led to the development of integrated curricula in which the knowledge base related to basic medical sciences has been greatly restricted. The time allocated to pathology teaching in medical schools has been decreased. The challenge for educators is to introduce effective methods of learning pathology into an integrated, student-centred curriculum. The aim of this study is to assess the tissue derived from cadaveric material and report its potential for use in teaching histopathology.

Methods: We have previously reported how we use cadavers' medical histories when introducing students to their 'first patient'. The medical histories of the seventeen cadavers that were dissected during one academic session were reviewed for evidence of reported pathology. During dissection unexpected pathological findings were noted. Standard histological processing was carried out on pathological tissue from the cadavers, a prosection and a specimen which was displayed in a museum pot. These specimens were then assessed for educational value by an expert clinical histopathologist.

Results: We find that the availability of a real medical history combined with gross and microscopic pathology encourages integration of basic medical sciences and promotes the learning of both gross and microscopic pathology in the dissecting room.

Conclusion: The dissecting room provides ample material to introduce pathological concepts to undergraduate medical students and this material is a valuable resource for teaching histopathology.
\end{abstract}

Keywords: dissection; gross anatomy education; histopathology; medical education; pathology education

Anatomy 2015;9(1):26-33 C2015 Turkish Society of Anatomy and Clinical Anatomy (TSACA)

\section{Introduction}

The study of pathology has played a pivotal role in developing an understanding of disease for at least three millennia. Educational dissections of living and dead humans were performed and reported as early as $300 \mathrm{BC}$ by both Herophilos of Alexandria (ca. 335-280 BC) and Erasistratos (ca. 304-245 BC). ${ }^{[1-4]}$ Two millennia would pass before Johannes Muller (1801-1858) became one of the first to use the microscope to analyse tissue. His student Rudolph Virchow used the microscope routinely in his work learning the title 'father of modern pathology, ${ }^{[5]}$
Digital or virtual pathology has been a central part of a 'quiet revolution' in medical and science education. ${ }^{[6]}$ The relatively recent introduction of digital pathology has had several beneficial educational consequences including improved student satisfaction, increased learning efficacy, increased student collaboration and performance. ${ }^{[7,8]}$ In addition instructor satisfaction is increased with virtual microscopy ${ }^{[0]}$ and when questioned students support an integrated approach utilizing digital slides and teaching histopathology alongside histology. ${ }^{[10]}$ In addition, this technology potentially allows sparse material to be used by increasing numbers of students. ${ }^{[1]}$ 
Pathology and histopathology still lie at the core of medical knowledge today and are just as important in other closely allied professional courses such as Dentistry and Veterinary Medicine. Medical curricula in the United Kingdom have undergone fundamental reforms since the first publication in 1993 of the General Medical Council recommendations in Tomorrow's Doctors, (GMC, 2009) and this process is on-going.

The profile of pathology as well as other basic medical sciences such as anatomy has been under pressure as the number of hours devoted to discipline-based teaching has been progressively reduced ${ }^{[12]}$ with the aim of limiting factual overload and to make way for the additional clinical and communication skills training required by modern medical graduates. ${ }^{[1,14]}$ Experts in pathology recognise the loss of visibility of tissue pathology in curricula. ${ }^{[15]}$

The study of pathology has been reduced although knowledge of pathological processes remains an essential prerequisite to an understanding of medicine. ${ }^{[16]}$ This change is due to increasing constraints on an overloaded curriculum but in part, also due to use of innovative teaching methods such as web resources and interactive computer assisted learning programs. ${ }^{[12]}$ Concurrently there has been a move from discipline based courses to integrated courses. Kumar et al. ${ }^{[17]}$ suggest some $51 \%$ of schools surveyed have some integration of systemic pathology and $65 \%$ for clinical pathology. An unexpected consequence of this change may include medical graduates failing to considering pathology as a potential career ${ }^{[18-20]}$ exacerbating the diminishing visibility of the subject. In addition there has been a decline in the use of the post mortem for teaching, this despite the positive opinion of medical educators regarding the value of such examinations. ${ }^{[1,22]}$ Although some may raise reservations ${ }^{[23]}$ most students generally regard post mortems positively. ${ }^{[24]}$

Burton $^{[3]}$ suggests many good reasons why pathology should be taught including, to promote the understanding of the pathological basis of disease, to introduce the use of the language of medicine and to gain an understanding of evidence based medicine. In addition, he suggests that pathology education allows students the important opportunity to observe pathology as a subject and meet working pathologists.

Given the changes in medical education described, every opportunity should be taken to promote pathology education. Currently medical education utilizes a combination of traditional teaching methods such as lectures and seminars as well as newer methods such as web based self-directed e-learning modules ${ }^{[25]}$ and teaching resources such as image / audio archives and museum audio tours. ${ }^{[26,2]}$ The Royal College of Pathologists have pro- duced a series of bespoke podcasts for medical education (www.e-pathpots.org.uk). Pathological changes discovered in the dissecting room can supplement these teaching methods and be used to link normal anatomy with disease and clinical practice ${ }^{[2,2,2]}$ the aim being to integrate pathology teaching across disciplines. ${ }^{[30]}$

It has been suggested that the discovery of pathology such as cancer in the dissecting room can excite students ${ }^{[31]}$ and Magrill et al. ${ }^{[32]}$ report the ad boc use of histology to investigate cancer in one cadaver. We have previously described a method of utilizing the dissecting room to teach gross pathology during anatomical dissec$\operatorname{tion}^{[33]}$ and this has been emulated by other authors. ${ }^{[34]}$

The purpose of this study is to systematically describe the appearance of histopathology in a consecutive series of 17 cadavers dissected during one academic session at the School of Medicine, University of St Andrews. We aim to determine its potential usefulness, as judged by an expert pathologist, as a resource for the teaching of histopathology to medical undergraduates. In addition, tissue samples were also retrieved and processed from one abdominal prosection and one 'potted' specimen to judge their usefulness for teaching and the effect of time on the histological appearance of such specimens.

\section{Materials and Methods}

The cadavers consisted of 11 males and 6 females, with ages ranging from 68 to 92 years old. Each cadaver was preserved by standard infusion with a Cambridge Formulation Fixative 99\% alcohol, formaldehyde, phenol and glycerol.

Brief medical histories for each cadaver were obtained from consultation with their General Practitioner and the cause of death was derived from hospital notes and death certificates. These medical histories were reviewed in order to identify likely pathology and the renal, respiratory, gastrointestinal, cardiovascular and nervous systems were examined and examples of gross pathology noted. The abdominal prosection used as a source of tissue sample was derived from a 97-year-old female; the cadaver had been in the department for 2 years and was preserved as described above. There was no available medical history. The potted specimen of brain was taken from the University of St Andrews Medical School historical collection. No medical history or preservation information was available for this specimen.

Prior to dissection relevant pathology was photographed using a Nikon D40X SLR camera and then small representative samples of pathological tissue were fixed in formalin, processed and embedded in paraffin wax. Standard $5 \mu \mathrm{m}$ thick sections were cut and stained with Haematoxylin and Eosin (H\&E). Subsequently rep- 
resentative histopathology was photographed using an Olympus BX51 microscope and camera.

\section{Results}

The results are presented in Table $\mathbf{1}$ and selected cases discussed in detail below. In addition, of the normal tissue present in the biopsies, blood vessels and kidney were well preserved as was the spleen. Less well preserved included portions of the gastrointestinal tract and liver which showed marked autolytic changes.

Most cadavers yielded gross pathology. These showed excellent preservation under histological examination and yielded identifiable histopathology. We were unable to retrieve useful specimens from several cadav-

Table 1

Results for the 17 cadavers, one prosection and one 'potted' specimen.

\begin{tabular}{|c|c|c|c|c|c|}
\hline $\begin{array}{l}\text { Cadaver, prosection } \\
\text { or potted specimen }\end{array}$ & Age & Sex & $\begin{array}{l}\text { Pathology described } \\
\text { in History }\end{array}$ & $\begin{array}{l}\text { Gross pathology } \\
\text { seen on dissection }\end{array}$ & $\begin{array}{l}\text { Histopathology } \\
\text { retrieved }\end{array}$ \\
\hline 1 & 88 & $\mathrm{M}$ & $\begin{array}{l}\text { Cerebrovascular disease, chronic } \\
\text { renal failure, Alzheimer's disease, } \\
\text { hypothyroidism, hypertension }\end{array}$ & Gallstones, splenic artery aneurysm & $\begin{array}{l}\text { Wall of splenic artery } \\
\text { aneurysm }\end{array}$ \\
\hline 2 & 83 & M & $\begin{array}{l}\text { Myocardial infarction, Pulmonary } \\
\text { fibrosis, non-Hodgkin lymphoma, gout }\end{array}$ & Pulmonary fibrosis, gout & Pulmonary fibrosis \\
\hline 3 & 76 & M & $\begin{array}{l}\text { Glioblastoma, previous cerebrovascular } \\
\text { disease, osteoarthritis }\end{array}$ & $\begin{array}{l}\text { Glioblastoma, old cerebrovascular } \\
\text { infarct }\end{array}$ & Frontal lobe glioblastoma \\
\hline 4 & 82 & M & $\begin{array}{l}\text { Ischaemic heart disease, pulmonary } \\
\text { oedema, duodenal ulcer }\end{array}$ & Abdominal aortic aneurysm & None \\
\hline 5 & 88 & M & $\begin{array}{l}\text { Stroke, myocardial infarction, chronic } \\
\text { renal disease, aspiration pneumonia, } \\
\text { type II diabetes, 'twisted bowel' }\end{array}$ & Peritonitis, popliteal artery aneurysm & None \\
\hline 6 & 82 & $\mathrm{~F}$ & $\begin{array}{l}\text { Chronic obstructive pulmonary } \\
\text { disease, pneumonia, diverticulitis }\end{array}$ & Splenunculi & Splenunculi \\
\hline 7 & 87 & $\mathrm{~F}$ & $\begin{array}{l}\text { Metastatic gastric lymphoma, } \\
\text { hypertension, right hip osteoarthritis } \\
\text { and replacement, right cataract removal }\end{array}$ & $\begin{array}{l}\text { Hallux valgus, liver metastasis, } \\
\text { thickened stomach wall }\end{array}$ & Stomach MALToma \\
\hline 8 & 73 & M & $\begin{array}{l}\text { Mesenteric ischaemia, atrial fibrillation, } \\
\text { cardiomyopathy, bladder cancer, diverticulitis }\end{array}$ & $\begin{array}{l}\text { Abdominal aortic aneurysm, renal } \\
\text { cysts, renal stones, diverticulitis }\end{array}$ & Renal cyst \\
\hline 9 & 85 & M & $\begin{array}{l}\text { Carcinoma of pancreas \& liver } \\
\text { metastasis, carcinomatosis, } \\
\text { 'arthritis' }\end{array}$ & $\begin{array}{l}\text { Carcinoma of pancreas, } \\
\text { liver metastasis, } \\
\text { splenunculi }\end{array}$ & $\begin{array}{l}\text { Carcinoma of head of } \\
\text { pancreas\& liver metastasis, } \\
\text { ascending cholangitis }\end{array}$ \\
\hline 10 & 88 & $\mathrm{~F}$ & $\begin{array}{l}\text { Osteoarthritis, pulmonary fibrosis, previous } \\
\text { breast cancer, right cataract removal }\end{array}$ & Pulmonary fibrosis, mastectomy scar & Pulmonary fibrosis \\
\hline 11 & 91 & $\mathrm{~F}$ & $\begin{array}{l}\text { Bronchopneumonia, ischaemic left leg } \\
\text { osteoarthritis, myocardial infarction, } \\
\text { previous cervical carcinoma, dementia, } \\
\text { bilateral cataracts }\end{array}$ & $\begin{array}{l}\text { Ischaemic left leg, } \\
\text { osteoarthritis of knee }\end{array}$ & $\begin{array}{l}\text { Acutely inflamed inguinal } \\
\text { lymph nodes }\end{array}$ \\
\hline 12 & 74 & M & $\begin{array}{l}\text { Extensive metastatic spread from } \\
\text { unknown primary, polio, diverticulitis }\end{array}$ & $\begin{array}{l}\text { Scoliosis, kyphosis, } \\
\text { abdominal lymph nodes }\end{array}$ & $\begin{array}{l}\text { Squamous cell carcinoma } \\
\text { of unknown origin }\end{array}$ \\
\hline 13 & 86 & M & $\begin{array}{l}\text { Ruptured abdominal aortic aneurysm, } \\
\text { lung cancer, hypertension }\end{array}$ & $\begin{array}{l}\text { Ruptured abdominal aortic aneurysm, } \\
\text { lung mass, enlarged heart }\end{array}$ & Chondro-sarcoma of lung \\
\hline 14 & 87 & $\mathrm{~F}$ & $\begin{array}{l}\text { Myocardial infarction, gallstones, } \\
\text { 'kidney disease' }\end{array}$ & $15 \mathrm{~cm}$ long appendix, gallstones & None \\
\hline 15 & 90 & $\mathrm{~F}$ & $\begin{array}{l}\text { Bronchopneumonia, ischaemic heart } \\
\text { disease, pulmonary hypertension, } \\
\text { right cataract replacement }\end{array}$ & Right inguinal hernia, jaundiced & None \\
\hline 16 & 92 & M & $\begin{array}{l}\text { Renal cancer, lung metastasis, } \\
\text { osteoarthritis, bilateral cataract } \\
\text { replacement }\end{array}$ & Right renal mass, osteoarthritis & $\begin{array}{l}\text { Renal cancer, invasion of } \\
\text { renal vein, distant lung } \\
\text { metastasis, liver necrosis }\end{array}$ \\
\hline 17 & 68 & $\mathrm{M}$ & Non-Hodgkin lymphoma, hypothyroidism & General lymphadenopathy & None \\
\hline Prosection & 97 & $\mathrm{~F}$ & Unknown & Retroperitoneal mass & $\begin{array}{l}\text { Squamous cell carcinoma } \\
\text { of unknown origin }\end{array}$ \\
\hline Potted specimen & Unknown & Unknown & Unknown & Unknown & Metastatic melanoma \\
\hline
\end{tabular}




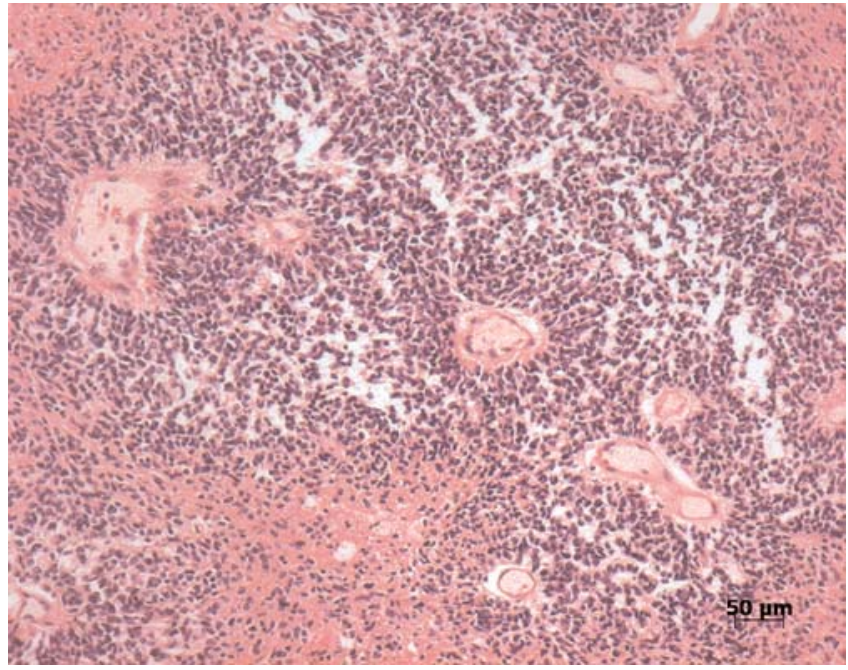

Figure 1. Malignant brain tumour with features consistent with a glioblastoma.

ers due to problems attributable to fixation. A case by case description of interesting pathology is provided below.

\section{Cadaver 3 - Glioblastoma}

This 76-year-old male died from the effects of a glioblastoma. He had a previous history of cerebrovascular disease and this condition was clearly visible on gross dissection of his brain. No tumour deposits were identified in any other organs. A section taken from the lesion identified in the brain (Figure 1) shows a malignant tumour with an appearance consistent with a glioblastoma.

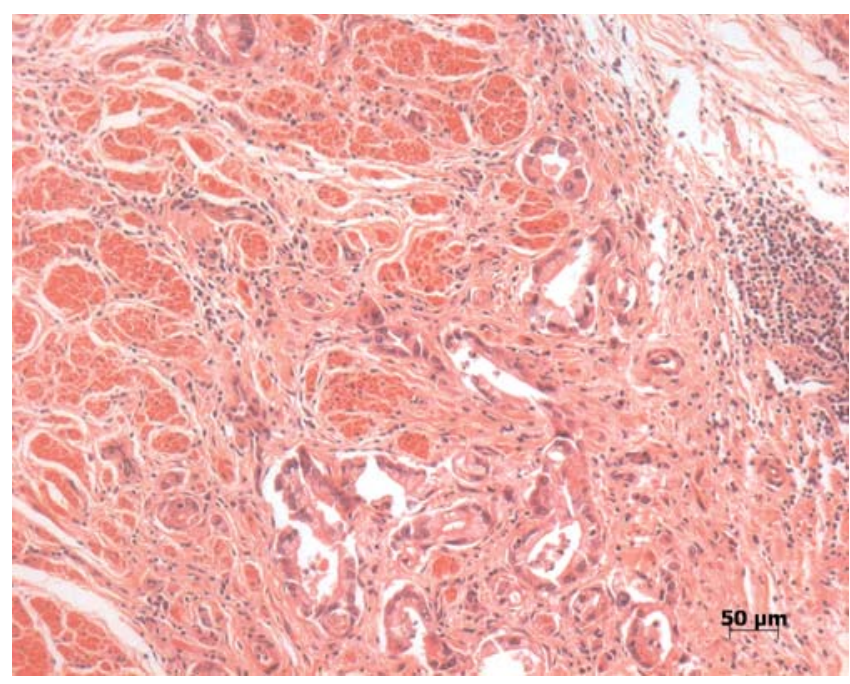

Figure 3. Pancreatic adenocarcinoma invading muscle of the duodenal wall.

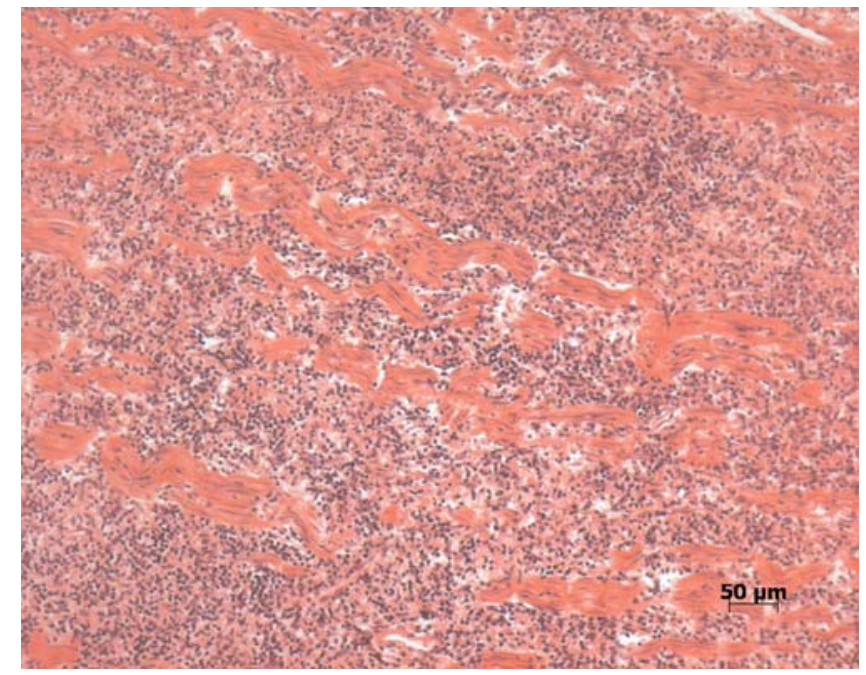

Figure 2. Non-Hodgkin lymphoma surrounding the gastro-oesophageal junction of cadaver 7. Neoplastic lymphoid cells infiltrate throughout the muscle layers of the oesophageal / gastric wall.

\section{Cadaver 7 - Non-Hodgkin lymphoma}

The cause of death for this 87 -year-old female was given as metastatic gastric lymphoma. When the intra-abdominal cavity was opened a hard mass was noted surrounding the gastro-oesophageal junction. A biopsy of this area is shown in Figure 2. No involvement of lymph nodes or spleen was identified macroscopically. Given the morphological appearance and the pattern of organ involvement, these appearances are most in keeping with a non-Hodgkin lymphoma of mucosa-associated lymphoid tissue (MALToma).

\section{Cadaver 9 - Pancreatic carcinoma}

This cadaver was an 85-year-old male who died from metastatic pancreatic carcinoma. On dissection of the abdominal cavity he had a pancreatic stent in situ, passing through a hard craggy mass in the head of the pancreas. A biopsy from this region is shown in Figure 3. Also present were multiple intra-hepatic abscesses associated with acute cholangitis.

\section{Cadaver 16 - Renal carcinoma}

This 92-year-old male died from a metastatic renal cell carcinoma. Gross dissection revealed an obvious renal tumour in the left kidney and pulmonary metastasis. Histology of the renal lesions revealed an undifferentiated carcinoma (Figure 4).

\section{Prosection - Retroperitoneal carcinoma}

The prosection of a 97-year-old female was also examined and a large hard pale white tumour was noted in the 


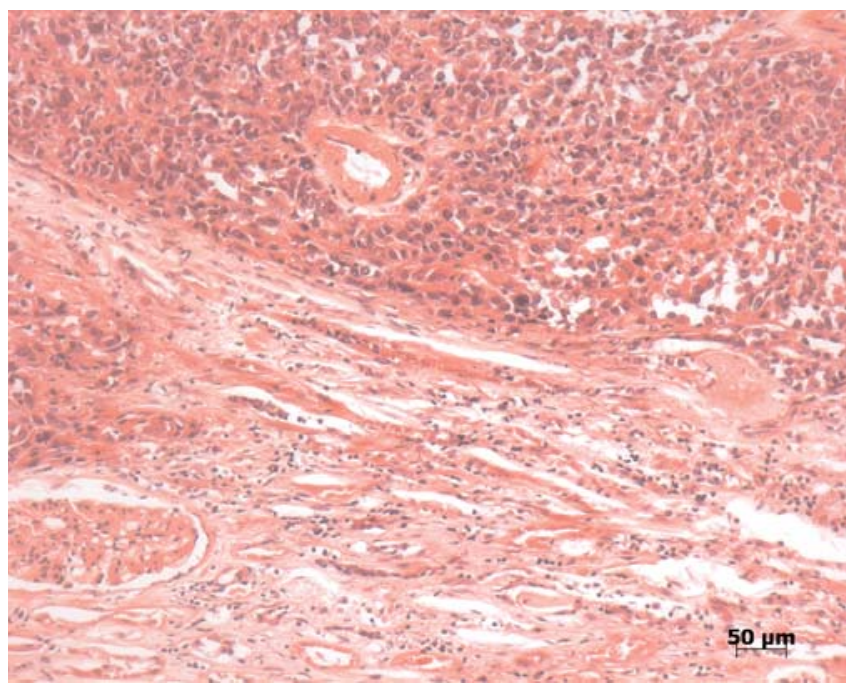

Figure 4. Histopathological appearance of the renal carcinoma.

left retroperitoneum spreading into the pelvic cavity. Histological analysis of a biopsy confirmed a squamous cell carcinoma (Figure 5).

\section{Potted Specimen - Brain metastasis}

This potted specimen of brain showed multiple well circumscribed pigmented metastatic deposits throughout the cerebral hemisphere and brainstem. On microscopic examination, the brain showed good preservation and a deposit of a poorly differentiated malignant tumour. These macroscopic appearances and features are most in keeping with metastatic malignant melanoma (Figure 6).

In most cadavers, both gross and microscopic pathology were retrievable and in many cases the histology revealed identifiable pathology and so allowed specific diagnosis. Pathology was also identified in both the prosection and the potted specimen several years since their initial preservation.

\section{Discussion}

The Medical School at the University of St Andrews retains full body dissection and a notable part of our teaching is the provision of a brief medical history in the dissecting room. We encourage our students to see their

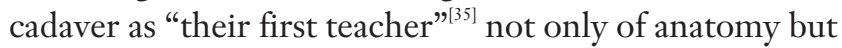
also of other medical sciences such as pathology. Anatomical teaching commences in their first week of student life and continues throughout their three year undergraduate education at the University of $\mathrm{St}$ Andrews. The central use of the cadaver in medical edu-

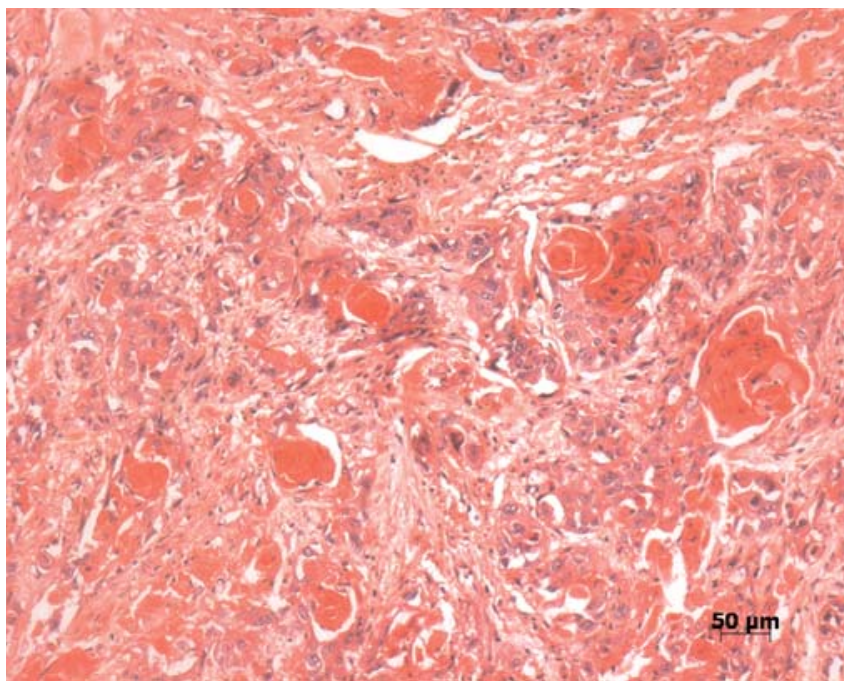

Figure 5. Keratinising squamous cell carcinoma from the prosection.

cation as one of several educational interventions aims to effectively increase transfer of basic scientific knowledge. $^{[36]}$

We have previously shown that cadaveric dissection provides excellent opportunities to introduce and discuss gross pathologies to undergraduate medical students, ${ }^{[33]}$ providing a basis for detailed formal study of the disorder later in the curriculum. In addition, surgical interventions (for example a pancreatic stent) and anatomical variations (e.g. long appendix) are common and provide aids in teaching when attempting to bridge the perceived gap between preclinical sciences and clinical medicine.

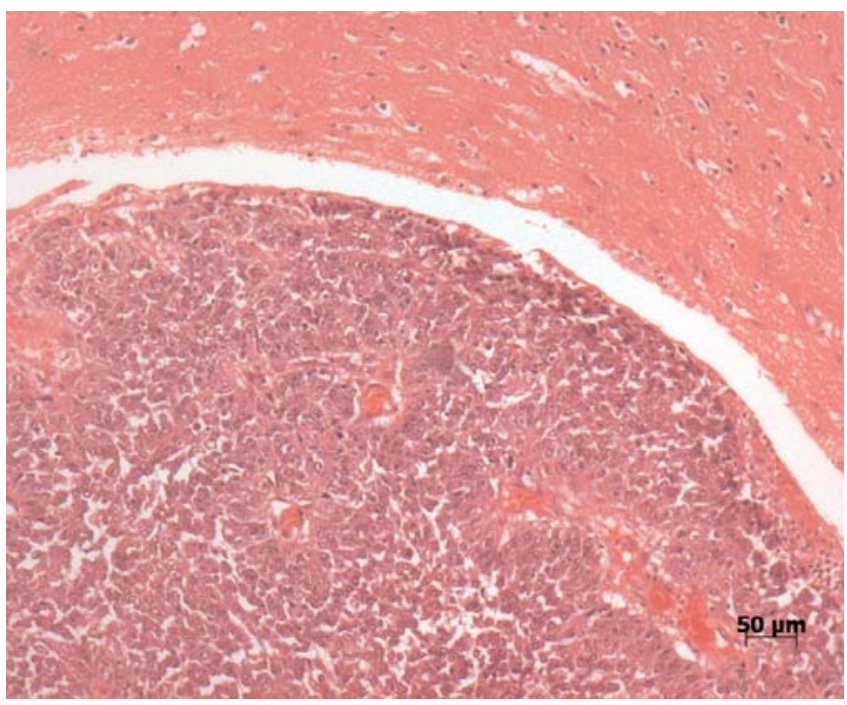

Figure 6. Multiple deposits of tumour in the potted specimen, a brain slice, showing an appearance consistent with metastatic malignant melanoma. 
In this study, we have extended our previous findings to show that the microscopic preservation of pathological changes in cadavers is excellent and provides additional educational material for teaching histopathology in an integrated curriculum. Chapman et al. ${ }^{[37]}$ reported poor preservation of tissues derived from cadavers. Although not all cadaveric tissue preservation is perfect in our study, it resembles that found in post mortem histology and it is certainly useful for teaching.

In addition we have shown that older tissues from a prosection and a specimen in a museum pot remain a useful resource for teaching several years after preservation. The histopathology described ranged from the common to the rare and unexpected. Pathological concepts such as invasion and distant metastasis are revealed in the cadavers and provide an introduction to the pathophysiology of disease.

Pathology has traditionally been formally taught via lectures, practical classes and clinico-pathological conferences. Integrating pathology into the core curriculum remains a challenge for medical educators. ${ }^{[38,39]}$ Knowledge of the processes leading to a pathological diagnosis, such as biopsy, tissue preservation, tissue processing and tissue staining are lacking in undergraduate medical education although it has been suggested by some authors these should be part of the pathology core curriculum. $^{[40]}$

We are now exploring the following strategies for the teaching of histopathology alongside the gross pathology present in the dissecting room;

- Encourage students to fill in pathology request forms requesting histological processing of pathology samples.

- Encourage students to 'follow up' biopsies taken during dissection ${ }^{[32]}$ and give them the opportunity to meet with pathologists to review slides, and if possible reach a tissue diagnosis. We acknowledge that there is more to histopathological diagnosis than a routine $\mathrm{H} \& \mathrm{E}$ stain, part of the follow up may include the use of immunohistochemistry to elucidate a definitive diagnosis. For example lesions from cadavers 7, 9 and 16 and the potted specimen may have benefited from further investigation.

- Develop clinico-pathological cases based upon the histopathology retrieved during dissection and patient histories. ${ }^{[4]]}$

- Develop Pathology Student Selected Components (SSC) based on the cadaveric pathology present and use this to introduce the concept of 'research' based on background reading about the pathology identified in 'their first teacher'.

- Staff may predict common conditions and integrate cases with virtual microscopy ${ }^{[42]}$ to complement the gross pathology expected at dissection.

These approaches have several aims. Principally, they are intended to promote student contact with pathology and pathologists and to introduce the language and processes of pathology which are currently lacking in our curriculum. For example, filling in a pathology request form introduces the student to written professional communication and to the information required on a request form.

It is envisaged that students following up the cadaveric biopsies and giving presentations on the pathology identified will be introduced to research. This may be integrated with SSCs, form a basis for ClinicoHistologic Conferences ${ }^{[4]}$ or provide a basis for research based seminars. ${ }^{[4]}$ Pathology grand rounds in the dissecting room could be developed where students would present the gross and microscopic pathology of their cadaver to faculty and classmates.

These novel approaches require flexibility. We have encouraged professional pathologists to become involved in the dissecting room, but we are aware that time constraints are ever present. Similarly histological processing of tissues requires time and resources and there are financial consequences to consider when requesting repeated tissue processing.

We have no control over the pathology present in each year's cadavers although overall pathology is common. Pathology archives are common in medicine and a collaborative archive of cases in a wiki format is an attractive option for further investigation. ${ }^{[45]}$

In addition, the reinforcement of pathology in our curriculum increases the resources available for assessment. For example McMahon and Benbow ${ }^{[46]}$ describe an OSCE station based on death certification: in our situation OSCE stations could be created based on the correct completion of pathology request forms.

We have shown that gross pathological material present in the dissecting room can be used for teaching. ${ }^{[3]]}$ We have extended this finding in this present study to show that cadaver-derived material is of good enough quality to be used in histopathology teaching and we have discussed ways of utilizing this rich resource. We believe that the dissecting room remains a neglected source of material which may be used to teach essential sciences in a modern integrated medical course. 


\section{Acknowledgement}

The authors would like to thank Prof Wojciech Pawlina for his helpful comments on an earlier draft of this paper.

\section{References}

1. Underwood JCE. General and systemic pathology. 5th ed. London: Churchill Livingstone; 2009. p. 4-5.

2. Burton JL. A bite into the history of the autopsy: from ancient roots to modern decay. Forensic Sci Med Pathol 2005;1:277-84.

3. Burton JL. Teaching pathology to medical undergraduates. Curr Diagn Pathol 2005;11:308-16.

4. Vollmer E, Goldmann T. Pathology on the edge of interdisciplinarity. A historical epitome. Rom J Morphol Embryol 2011;52: S223-30.

5. van den Tweel JG, Taylor CR. A brief history of pathology: preface to a forthcoming series that highlights milestones in the evolution of pathology as a discipline. Virchows Arch 2010;457:3-10.

6. Kumar RK, Velan GM. Learning across disciplines using virtual microscopy: new approaches. In: Mendez-Vilas A, Diaz J, editors. Microscopy: science, technology, applications and education. Badajoz, Extremadura: Formatex Research Center; 2010. p. 1467-73.

7. Braun MW, Kearns KD. Improved learning efficiency and increased student collaboration through use of virtual microscopy in the teaching of human pathology. Anat Sci Educ 2008;1:240-6.

8. Triola MM and Holloway WJ. Enhanced virtual microscopy for collaborative education. BMC Med Educ 2011;11:4.

9. Collier L, Dunham S, Braun MW, O’Loughlin VD. Optical versus virtual: Teaching assistant perceptions of the use of virtual microscopy in an undergraduate human anatomy course. Anat Sci Educ 2012;5:10-9.

10. Kumar RK, Freeman B, Velan GM, De Permentier PJ. Integrating histology and histopathology teaching in practical classes using virtual slides. Anat Rec B New Anat 2006;289:128-33.

11. Guzman M, Judkins AR. Digital pathology: A tool for 21st century neuropathology. Brain Pathol 2009;19:305-16.

12. Reid WA. Pathology in the medical curriculum in the United Kingdom. J Vet Med Educ 2007;34:390-5.

13. McHanwell S, Davies DC, Morris J, Parkin I, Whiten S, Atkinson M, Dyball R, Ockleford C, Standring S, Wilton J. A core syllabus in anatomy for medical students - Adding common sense to need to know. Eur J Anat 2007;11:S3-18.

14. Drake RL, McBride JM, Lachman N, Pawlins W. Medical education in the anatomical sciences: the winds of change continue to blow. Anat Sci Educ 2009;2:253-9.

15. Mattick K, Marshall R, Bligh J. Tissue pathology in undergraduate medical education: Atrophy or evolution? J Pathol 2004;203:8716.

16. Weedon D. Whither pathology in medical education? Med J Aust 2003;178:200-2.

17. Kumar K, Indurkhya A, Nguyen H. Curricular trends in instruction of pathology: a nationwide longitudinal study from 1993 to present. Hum Pathol 2001;32:1147-53.

18. Domizio P, Wilkinson M. Pathology teaching in the twenty-first century. Clin Teach 2006;3:53-9.

19. Hung T, Jarvis-Selinger S, Ford JC. Residency choices by graduating medical students: why not pathology? Hum Pathol 2011;42: $802-7$.
20. Mortimer R, Lakhani S. Pathology in education and practice: a time for integration? Aust Health Rev 2008;32:319-21.

21. Burton JL. Medical educators' personal attitudes towards the necropsy. J Clin Pathol 2003;56:950-1.

22. Burton JL.The autopsy in modern undergraduate medical education: a qualitative study of uses and curriculum considerations. Med Educ 2003;37:1073-81.

23. Benbow EW. Medical students' views on necropsies. J Clin Pathol 1990;43:969-76.

24. Conran P, Nowacek G, Adams T, Smith L. Medical students' attitudes towards the autopsy. Acad Med 1996;71:681-3.

25. Tse MM, Lo LW. A Web-based e-learning course: integration of pathophysiology into pharmacology. Telemed J E Health 2008;14:919-24.

26. Kayser K, Ogilvie R, Borkenfeld S, Kayser G. E-education in pathology including certification of e-institutions. Diagn Pathol 2011;6:S1-11.

27. de Jong PGM, Riedstra AW, Willems LNA, Bolk JN. Teaching anatomy and pathology using MP3 audio tours at the Leiden Museum for Anatomy and Pathology. J Int Assoc Med Sci Educ 2010;20:14-7.

28. Ellis H. Teaching in the dissecting room. Clin Anat 2001;14:14951.

29. Chun J, Theologou T, Ellis H. Incidence of cardiovascular disease in the dissecting room: A valuable teaching asset. Clin Anat 2007; 20:89-92.

30. Young B. Teaching anatomical pathology in an integrated selfdirected learning programme: The Newcastle experience. Pathology 1993;25:423-5.

31. Terman SA, Metcalf WK, Metcalf NF, Miller D. Cancer casefinding in gross anatomy to stimulate student interest. J Iowa Med Soc 1975;65:360-3.

32. Magrill D, Mirnezami R, Ellis H. Intra-abdominal pathology in the dissecting room: a study of incidence and its value in teaching. Anatomy 2008;2:22-7.

33. Wood A, Struthers K, Whiten S, Jackson D, Herrington CS. Introducing gross pathology to undergraduate medical students in the dissecting room. Anat Sci Educ 2010;3:97-100.

34. Malley RC, Assenheimer D, Chapman JA, Choi-Lundberg, D, Williams AM. Cadaver path: Integration of anatomy and anatomical pathology in the dissection laboratory. Clin Anat 2011;24:4056.

35. Winkelmann A, Güldner FH. Cadavers as teachers: the dissecting room experience in Thailand. BMJ 2004;329:1455-7. Erratum in: BMJ 2005;330:82.

36. Norman G. Teaching basic science to optimize transfer. Med Teach 2009;31:807-11.

37. Chapman JA, Williams AMM. The suitability of human cadaveric tissue for the generation of histology teaching class slides. Clin Anat 2011;24:404.

38. Marshall R, Cartwright N, Mattick K. Teaching and learning pathology: a critical review of the English literature. Med Educ 2004;38:302-13.

39. Magid MS, Cambor CL. The integration of pathology into the clinical years of undergraduate medical education: a survey and review of the literature. Hum Pathol 2012;43:567-76.

40. Carr NJ, Olmos M, Bushnell J. Delivering a pathology curriculum in an integrated medical course. Virchows Arch 2008;453:369-75. 
41. Weurlander M, Masiello I, Soderberg M, Wernerson A. Meaningful learning: student's perceptions of a new form of case seminar in pathology. Med Teach 2009;31:e248-53.

42. Durosaro O, Lachman N, Pawlina W. Use of knowledge-sharing web-based portal in gross and microscopic anatomy. Ann Acad Med Singap 2008;37:998-1001.

43. Shaw PA, Friedman ES. Clinico-histologic conferences: histology and disease. Anat Sci Educ 2012;51:55-61.

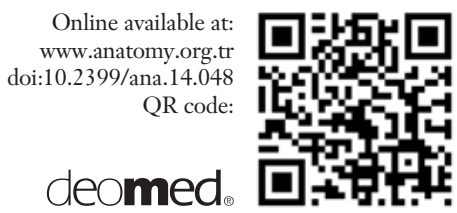

44. McBride JM, Prayson RA. Development of a synergistic casebased microanatomy curriculum. Anat Sci Educ 2008;1:102-5.

45. Boulos MN, Maramba I, Wheeler S. Wikis, blogs and podcasts: a new generation of web-based tools for virtual collaborative clinical practice and education. BMC Med Educ 2006;6:41.

46. McMahon RFT, Benbow EW. Designing assessment of pathology in the undergraduate curriculum. Diagn Histopathol 2008;14:4538.

\section{Correspondence to: Andrew Wood, MBChB}

Department of Laboratory Medicine (Pathology), Royal Infirmary of Edinburgh, 51, Little France Crescent, Little France, Edinburgh EH16 4SA, UK Phone: +4401315367138

e-mail: andrew.x.wood@nhslothian.scot.nhs.uk

Conflict of interest statement: No conflicts declared.

This is an open access article distributed under the terms of the Creative Commons Attribution-NonCommercial-NoDerivs 3.0 Unported (CC BY-NCND3.0) Licence (http://creativecommons.org/licenses/by-nc-nd/3.0/) which permits unrestricted noncommercial use, distribution, and reproduction in any medium, provided the original work is properly cited. Please cite this article as: Wood A, Whiten S, McVee J, Issberner J, Jackson D, Herrington CS. Histopathology from the dissecting room: Are cadavers a suitable source of educationally useful histopathology specimens? Anatomy 2015;9(1):26-33. 